\title{
The Role of the Program of Development of Corporate Culture in Moderating the Values of The Company against the Employee Engagement in PT PLN (Persero) Parent Unit is the Region of North Sumatra
}

\author{
Syifa Sakinah ${ }^{1}$, Nazarudin $^{2}$, Isfenti Sadalia ${ }^{3}$ \\ ${ }^{1,2,3}$ Master of Management Universitas Sumatera Utara, Indonesia \\ Corresponding Author: Syifa Sakinah
}

\section{ABSTRACT}

This research included in the study puantitatif. While the research design used in this research is the analysis of correlation, namely the type of research conducted with the aim of detecting the extent to which variations in one factor are associated (correlated) with one or more other factors based on the correlation coefficient. The purpose of the research, namely to explain the influence and hypothesis testing by analyzing the various data in the field. In the context of this study is to obtain the facts of the phenomena that exist and find information in a factual description of the factors increase employee engagement in PT PLN (Persero) Parent Unit is the Region of North Sumatra. The population in this research is all employees PLN (Persero) Parent Unit is the Region of North Sumatra. This time recorded as many as 181 employees with the status of a permanent employee. The technique of determining the number of samples used Method Slovin so that the number of samples in this study amounted to 65 respondents. Data Collection method used in this research are primary data and secondary data. The results showed that the Values of the Company as a significant influence on the formation of Employee Engagement in PT PLN (Persero) Parent Unit is the Region of North Sumatra. PT PLN (Persero) also has a program to foster employee engagement, namely: Employee Gathering, the Visit of a Senior Leader, LIQUID and Code of Conduct. On the basis of this, the researchers enter the Program of Development of Corporate Culture as a
\end{abstract}

moderating variable, with the assumption that the program is able to drive employee engagement through the value of the company. The results showed that the Program of Development of the Culture of the Company contained in PT PLN (Persero) to be able to participate moderating variable value of the Company in influencing employee engagement. This means that the understanding of the employees against the Values of the Company will be more effective with the Program of Development of Corporate Culture in PT PLN (Persero) Parent Unit is the Region of North Sumatra.

Keywords: Corporate Culture, Corporate Values, Employee Engagement

\section{INTRODUCTION}

One of the missions of the strategic government of Joko Widodo in the second round this is to focus on the development of Human Resources (HR) towards the era of technology and information. The government has laid the foundation of infrastructure development intensive that not only the transport, but also energy infrastructure, information and communication technology as a basic prerequisite. But nevertheless it is necessary Human resources to operate, the Human resources that have competence in their respective fields. The development of Human resources, said President Jokowi, is the capital of the largest and strongest must 
be owned Indonesia (www.indonesia.go.id, 2019).

As the movers of the organization, Human resource management the right to improve the performance of the organization. This is in line with some of the results of the research, including that carried out by Setiawan (2015) where he found the management of the Human resources professionals proved to be very closely its influence on the performance of the company. A similar sentiment was expressed by Sadikin (2010) which states that Human resource development the right is able to face the turbulence of a dynamic company. This is a consideration for the company, because unfortunately many companies are still focusing on the work of administration and personnel, whereas the function and role of Human resources is already widespread and becoming a business partner of the company. One company that is concerned with the problems of the development of qualified Human resources is the PT PLN (Persero).

PT PLN (Persero) is a state-owned company that handles the problems of availability of electricity in the entire territory of Indonesia, ranging from urban areas to rural areas that have difficult access. Needs electricity as energy has become a staple of the community. The company has customers in the form of the whole people of Indonesia. As a leading provider of electricity, of course, companies often face obstacles that result in a disruption of the supply of electricity to households. This problem of course brings complaints from customers. As a company that provides electrical, PT PLN (Persero) continues to bersinerji become the company that provides the best quality service.

In line with this, PT PLN (Persero) which has a vision to become a company leading power in Southeast Asia and the 1 choice of customers for energy solutions also perform the transformation to enhance Human resource development in order to improve the quality of work and performance of employees. With performing a variety of missions, including: 1) Run the electricity business and other related fields, oriented on customer satisfaction, the members of the company and shareholders. 2)Make the electric power as a media to improve the quality of life of the community. 3)Strive for power to drive economic activity. 4)Run an environmentally friendly business activities.

Not only the vision and mission, PLN also has a value-the value of the company which becomes a guide for all employees PLN to behave in the work. As for the values of the company PLN is:1)Trust, promise and commitment. Responsible for tasks, decisions and actions are performed. Hold fast to the moral and ethical values.2)Competent, Improve the competence of themselves to answer the challenges are always changing. Help others learn. Complete the task with quality better.3) Harmonious, Appreciate everyone of any background. Like to help others. To build a conducive working environment. 4)Loyal, Keep the good name of the fellow employees, leaders, STATE, and Country. Willing to sacrifice to achieve a larger goal. Obedient to the leadership of the extent not inconsistent with law and ethics.5)Adaptive, Quickly adjust yourself to be better. Constantly make improvements to follow the development of technology. Be proactive. 1)Collaborative, Give an opportunity to all parties to contribute. Open in working together to produce added value. Moving the utilization of various resources for a common goal.

These values serve as guidelines for all employees PLN in being and acting in the work environment. Values that have been imprinted on eventually formed the culture of the organization. Organizational culture as the values that are supported by the organization or philosophy that guides the discretion of the organization to employees and customers, or the way work is done in the workplace, or the assumption and the basic belief that there is among the 
members of the organization. A strong organizational culture is able to increase the involvement of workers (employee engagement). It is shown from the results of research conducted by Puspita and Sembiring (2016) who found that simultaneous organizational culture significantly influence employee engagement employee of the territorial Office of PT perusahaan Listrik negara (Persero) West Kalimantan with the value of determination of $69,2 \%$.

As previously disclosed, PT PLN (Persero) is committed to provide the best services to customers. Of course the company's commitment to provide the best service in the end will back to the quality of Human resources owned by the company. One of the important factors that are owned TBSP so quality (both work and providing services) is attachment to the company and / or employee engagement.

Different studies show that employee engagement is closely related with the performance of the workers. The performance of the workers in the accumulation at the end gives a positive impact on the overall performance of the company. Workers who have high involvement showed: 1) their satisfaction with his work, 2) their commitment to the company and 3) their productivity is high (Armstrong, 2014). The involvement of workers is an issue that is sufficiently developed in the world of Human resource management. This issue is considered important because of the various survey shows that companies that employees have the involvement of workers is correlated with their income, such as a survey conducted by Gallup (Noe, Hodlenback, Gerhart and Wright, 2014).

As exposure above that employee engagement is closely related to productivity, even Gallup (2009) stated that companies that have employee engagement to his high is able to increase the profit of the company amounted to $12 \%$, so the company need to keep the index semployee engagement to getting better. PT PLN (Persero) also conducted a survey of employee engagement regularly every year since 2013. The following data of scores on employee engagement in PT PLN (Persero) and PT PLN (Persero) Parent Unit is the Region of North Sumatra from year 2015 to 2019 can be seen in Table 1.1 below:

Table 1.1: Score Employee Engagement in PT PLN (Persero)

\begin{tabular}{|c|c|c|}
\hline \multirow{2}{*}{ Year } & \multicolumn{2}{|c|}{ Scor Employee Engagement } \\
\cline { 2 - 3 } & PT PLN (Persero) & $\begin{array}{c}\text { PT PLN (Persero) Parent Unit } \\
\text { is the Region of North Sumatra }\end{array}$ \\
\hline 2015 & $78 \%$ & $79 \%$ \\
\hline 2016 & $80 \%$ & $81 \%$ \\
\hline 2017 & $79 \%$ & $82 \%$ \\
\hline 2018 & $79 \%$ & $80 \%$ \\
\hline 2019 & $84 \%$ & $85 \%$ \\
\hline
\end{tabular}

Source: Data of PT PLN (Persero) Parent Unit Region of North Sumatra, 2020

Based on the data in Table 1.1 is seen that the results of the survey of employee engagement in national and per the parent unit is volatile, meaning that employee engagement is still changing every year. While employee engagement is expected to have improving trend and also meet the target score employee engagement set by the Ministry of SOES, i.e. above $84 \%$. Can also be seen that the scores of employee engagement in national no one above $84 \%$ as the target that has been set. As for the only score of the year 2019 that touched on the figure of $84 \%$, this occurs because of changes to the measuring instrument and this encourages an increase scores on employee engagement in 2018 won $79 \%$ but in 2019, reaching $84 \%$, though still not able to achieve the targets of the Ministry of SOES, i.e. above $84 \%$.

It is also experienced by PT PLN (Persero) Parent Unit Region of North Sumatra, where prior to the policy in the measurement of a new Employee Engagement, yet never reach the target score set by the Ministry of state-owned enterprises. However, since the presence of such changes, the score employee engagement in PT PLN (Persero) Parent Unit is the Region of North Sumatra can reach $85 \%$. This suggests that the level of employee engagement in PT PLN (Persero) 
Parent Unit is the Region of North Sumatra is still changing every year.

In order to improve employee engagement in PT PLN (Persero) Parent Unit Region of North Sumatra, PT PLN (Persero) Parent Unit is the Region of North Sumatra has several programs strengthening company values as the form of increased employee engagement. As for the shapes of the activities of the Program of Development of the Culture of the Company, among others, are:1) Employee Gathering, an annual Event that is done to instill corporate values in the form of cheerful activity and game (games and fun), improve teamwork and relationships between employees.2) Visit the Management to the Unit Giving Appreciation, Visit the Senior management Leader, in terms of General Manager and the entire Senior Manager to give appreciation to those units that achievement or to achieve certain performance and provide coaching, mentoring, and counseling directly to the leadership of the unit and the employees of the unit.3) LIQUID (Leadership Quality Feedback), LIQUID or Leadership Quality Feedback is a program of Human resources was conducted to obtain advice, criticism, and input from employees to their leaders.4) COC (Code of Conduct), the Code of conduct is a means of meeting the employees and leaders to discuss the issues of corporate current, a variety of information, knowledge, and tips to achieve performance, as well as the planting guide the behavior of employees who are prepared based on the culture and values of the company to create a behavior and work culture that has the principles of Good Corporate Governance (GCG) which is conducted regularly every week on Monday, where this activity should be followed by all employees.
With the Program of Development of the Culture of this Company, should increase the engagement of employees. However, as scores obtained in employee engagement of employees of PT PLN (Persero), in particular the Parent Unit is the Region of North Sumatra, is still fluctuating, changing from year to year. While the trend score employee engagement is expected to continue to improve and increase. Score employee engagement remains volatile is suspected to be caused by the investment value-the value of the company which has not been achieved optimally. Research conducted by Puspita and Sembiring (2016) find that companies that have a strong organizational culture play a role in the formation of employee engagement in the Office of the State Electricity Company PT (Persero) West Kalimantan.

\section{LITERATURE REVIEW The Value of the Company}

Value-the value of the company is a statement of the value declared by the company to all stakeholders of the company (i.e. the owners, customers, suppliers, communities, government and employees) about what is-what are the beliefs of the main company (core beliefs) of the guidelines and the steps the company (Tessema,2019).

\section{Employee Engagement}

Noe, Hodlenback, Gerhart and Wright (2014) defines the involvement of workers as the totality of the workers in its commitment to the job and the company. Sejaumana workers assess important whether or not the work is in line with the involvement of workers. The involvement of workers is a strong positive feelings or involvement with the organization (Schermerhorn, Hunt, Osborn, and UhlBien, 2010). The involvement of workers as an expression of the workers both physically and emotionally to work. 
Syifa Sakinah et.al. The role of the program of development of Corporate Culture in moderating the values of the company against the employee engagement in PT PLN (Persero) Parent Unit is the Region of North Sumatra

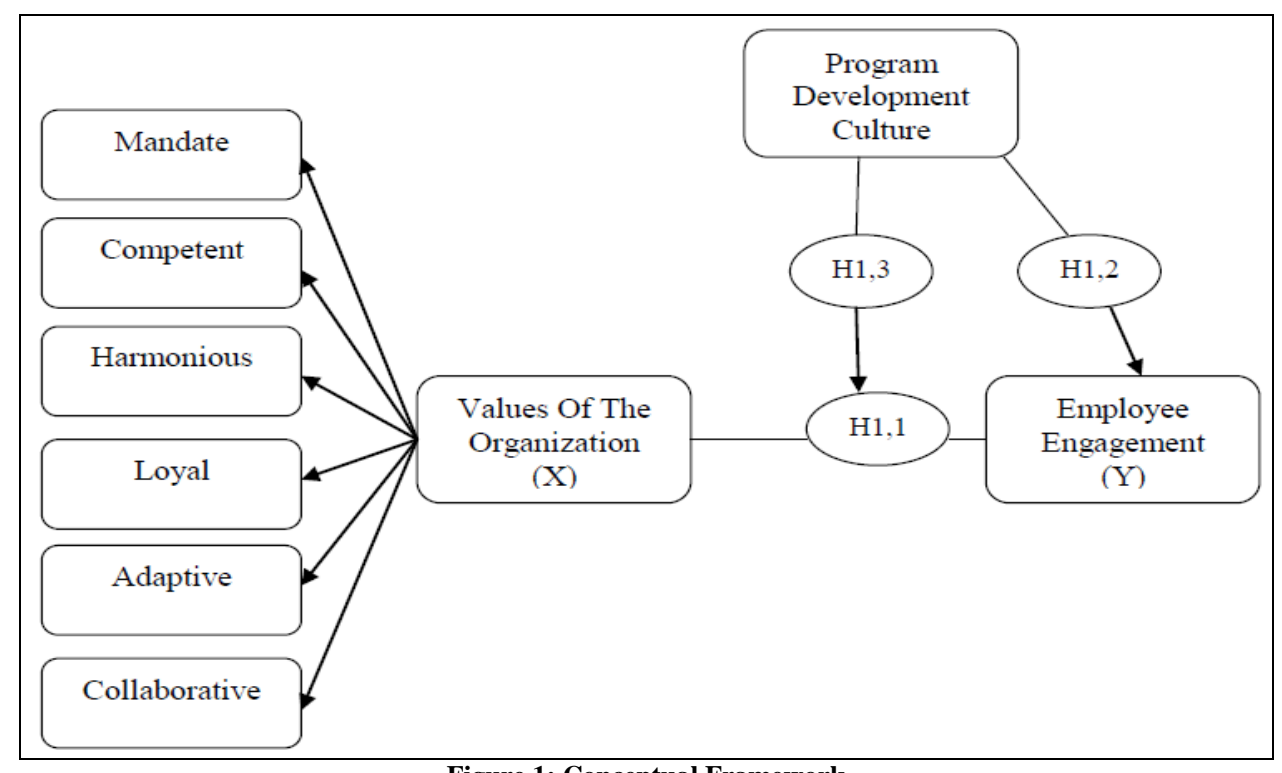

Figure 1: Conceptual Framework

\section{Hypothesis}

Based on the background research and the relationship between variables, then the hypothesis of the research:

1. There is a positive and significant influence between the Values of the Company (X1) on Employee Engagement (Y) in PT PLN (Persero) Parent Unit is the Region of North Sumatra.

2. There is a positive and significant influence between the Program of Development of Corporate Culture (X2) toward Employee Engagement (Y) in PT PLN (Persero) Parent Unit is the Region of North Sumatra.

3. The Program of Development of Corporate Culture (X2) row strengthens in moderating the influence of the Values of the Company (X1) on Employee Engagement (Y) in PT PLN (Persero) Parent Unit is the Region of North Sumatra.

\section{MATERIAL AND METHODS}

The research used is Quantitative Research. While the research design used in this research is the analysis of correlation, namely the type of research conducted with the aim of detecting the extent to which variations in one factor are associated (correlated) with one or more other factors based on the correlation coefficient (Sinulingga, 2017). The selection and use of the design is related to the purpose of the research, namely to explain the influence and hypothesis testing by analyzing the various data in the field. In the context of this study is to obtain the facts of the phenomena that exist and find information in a factual description of the factors increase employee engagement in PT PLN (Persero) Parent Unit is the Region of North Sumatra.

The population in this research is all employees PLN (Persero) Parent Unit is the Region of North Sumatra as much as 181 employees with the status of a permanent employee. The Technique of determining the number of samples used Method Slovin so that the number of samples in this study amounted to 65 people

Data Collection method used in this research are primary data and secondary data. Primary Data is data obtained directly from the source, observed and recorded by the researcher. The primary Data obtained through the technique of collecting data by survey. A Survey is a data collection technique is done by giving a set of questions or a written statement to the respondent to answer. The primary Data is taken from the results of the survey for qualitative data includes the perception of 
employees regarding the factors-factor the cause of the increase employee engagement in PT PLN (Persero) Parent Unit is the Region of North Sumatra. Secondary Data is data that comes from pt PLN (Persero) Parent Unit Region of North Sumatra, namely data obtained from the company relating to employment.

\section{RESULTS AND DISCUSSION}

The results showed that the Values of the Company as a significant influence on the formation of Employee Engagement in PT PLN (Persero) Parent Unit is the Region of North Sumatra. This is in line with the results of research conducted by Puspita and Sembiring (2016) which states that simultaneous values of the organization significantly influence employee engagement in the Office of the State Electricity Company PT (Persero) West Kalimantan. The same thing was done by Humairoh and Ward (2017) who found that the Culture of the Organization either directly or indirectly (through Job Satisfaction) and significant positive effect on Employee Engagement in the Company's Service Port. This shows that this is an important input for the management of PT PLN (Persero) Parent Unit is the Region of North Sumatra. This research is descriptive, in the sense of studying the attitude of the respondents (employees of PT PLN (Persero) Parent Unit Region of North Sumatra).

A positive attitude that is strongly relevant with the behavior (Baron and Branscombe, 2012). The results of description of respondents to the variable Value-value of the Company is 4,32 and is classified as "Very High". This suggests that employees have a strong stance against the company's Values in PT PLN (Persero). Enterprise live continue to be positive employees to action so that they can display the attitude of work in accordance with company values.

PT PLN (Persero) also have specific programs to foster employee engagement, namely: Employee Gathering, the Visit of a Senior Leader, LIQUID and Code of Conduct. On the basis of the halt certainly, researchers enter the Program of Development of Corporate Culture as a moderating variable, with the assumption that the program is able to drive employee engagement through Value-the value of the Company. The results showed that the Program of Development of the Culture of the Company contained in PT PLN (Persero) to be able to participate moderating variable Values in influencing employee engagement. This means that the understanding of the employees against the Values of the Company will be more effective with the Program of Development of the Culture of this Company.

Of the 4 Programs of Development of the Culture of the Company, then acquired Employee Gathering score average of 3.74 or classified as "Moderate", while 3 other programs gets the category of the attitude of "High". This indicates that the employees still consider the program Employee Gathering less effective in delivering their understanding of the implementation of the socialization / the formation of Value-the value of the Company. This becomes the input for the company to reconsider the material for this they give in Employee Gathering, don't let this program is entertainment and the participant does not take the benefit or educational. Need preparation materials which are more educative and relevant.

\section{Managerial Implications}

In order to obtain strategic advice and relevant, the researchers tried to conduct interviews with some respondents and the results of their input the researchers tried to summarize for can be input to PT PLN (Persero) Parent Unit is the Region of North Sumatra as follows:

\section{Management say hello}

Based on interviews with several employees (respondents) that the management, especially the Senior Leader is often to communicate with 
employees. This can be done through non-formal, giving motivation to the employees, casual discussion which does not always work.

2. A Program to increase the love on the job

Employees senior has the tendency is to love the work and the company, as with employees-new employees. Therefore, it is necessary to improve the activities to cultivate love, awareness, and loyalty to the company for employees-new employees. Such care program assets PLN to protect the assets of PLN damage and abuse.

3. The synergy between the employee and the company

This synergy is in the form of maintaining a harmonious relationship between the employee and the company. Companies also need to pay attention to the employees as the most valuable asset for the company. Another form is to maintain the friendship between employees. So as to create a pleasant working environment.

4. The program reward and punishment

In the implementation of value-the value of the company, management needs to consider giving awards to employees who are considered good in applying value-the value of the company, on the contrary management also provides penalties for employees who violate company's values.

5. CoC implemented in accordance with the schedule

Some employees assess the $\mathrm{CoC}$ is often not carried out according to the schedule and most of the employees are not active in participating in CoC.So it is necessary to give the opportunity to each person to speak in turn.

6. The measurement of competence

It is intended to measure the competencies of employees in accordance with company values.

7. The value of spirituality
In order to strengthen the implementation of the value-the value of the company, the management also need to instil the value of spirituality to ensure the behavior of the employees in accordance with company values.

\section{CONCLUSIONS AND \\ RECOMMENDATIONS \\ CONCLUSIONS}

Based on the purpose of the research and the results of the research are then able to deduce the following:

1. Value-the value of the Company has a positive and significant impact on Employee Engagement in PT PLN (Persero) Parent Unit is the Region of North Sumatra.

2. The Program of Development of Corporate Culture has a positive and significant impact on Employee Engagement in PT PLN (Persero) Parent Unit is the Region of North Sumatra.

3. The Program of Development of the Culture of the Company gives a positive impact in moderating the influence of the Values of the Company against the Employee Engagement in PT PLN (Persero) Parent Unit is the Region of North Sumatra.

\section{RECOMMENDATIONS}

Advice researcher from the research that has been done is as follows:

1. The results showed that the Program of Development of the Culture of the Company is able to moderate the company's values in shaping employee engagement. This becomes the input for the company to improve the quality and evaluation of existing programs, such as Program Employee Gathering perceived employee is not yet effective in shaping the values of the company.

2. In this study, there is the influence of the Company's Values through the Development of Corporate Culture as a moderating variable accounted for $64.0 \%$ of against the formation of Employee Engagement, the rest 36,0\% 
Syifa Sakinah et.al. The role of the program of development of Corporate Culture in moderating the values of the company against the employee engagement in PT PLN (Persero) Parent Unit is the Region of North Sumatra

influenced by other factors not measured in this study. It is to be input to further research could examine other variables, such as leadership and motivation in influencing employee engagement in PT. PLN (Persero) Parent Unit is the Region of North Sumatra.

\section{REFERENCE}

1. Abdurrahman, N.H., 2015. Manajemen Strategi Pemasaran, Bandung: CV. Pustaka Setia.

2. Salim, dkk. (2018). Focusing on Complaints Handling for Customer Satisfaction and Loyalty: The Case of Indonesian Public Banking. International Journal of Theory and Practice.

3. Alfani AD (2017). Dampak Type of Service Failure dan Service Recovery Strategy terhadap Anger dan Customer Loyalty. Jurnal Repositori Universitas Airlangga.

4. Boon Liat Cheng et al (2018). Service Recovery, Customer Satisfaction and Customer Loyalty: Evidence from Malaysia's Hotel Industry. International Journal of Quality and Service Sciences.

5. Briciet al (2016). The Effects of Trust, Commitment and Satisfaction on Customer Loyalty in the Distribution Sector.International Journal of Business and Management 4 (2).

6. Mowen, John dan Michael Minor. 2012. Perilaku Konsumen. Jakarta :Erlangga.

7. Chia-Chi Chang and Jung-Sung Hung (2018). The Effect of Service Recovery and Relational Selling Behavior on Trust, Satisfaction, and Loyalty. International Journal of Bank marketing. https://doi.org/10.1108/IJBM-07-20170160.

8. Damiyana Damdan (2017). Hubungan Kegagalan Layanan dan Loyalitas Pelanggan Pada Perusahaan Penerbangan Komersial. Jurnal Lentera Bisni. Vol. 6 No. 1/ISSN 2252-9993

9. Fajar, Laksana, 2008. Manajemen Pemasaran. Yogyakarta: Penerbit Graha Ilmu.

10. Fryta Ganita (2019). Pengaruh Service Recovery Terhadap Loyalitas Pelanggan dengan Kepuasan sebagai Variabel Mediasi. Jurnal Ilmu Manajemen Vol. 7 No. 1 Universitas Negeri Surabaya.
11. Ghozali, Imam, 2013. Aplikasi Analisis Multivariate dengan Program SPSS. Yogyakarta: Badan Penerbit BPFE.

12. Helmi dan Andjarwati (2019). Pengaruh Kualitas Layanan dan Pemulihan Layanan Terhadap Loyalitas Pelanggan dengan Kepuasan sebagai variabel Intervening (Studi Pada Nasabah Bank Mandiri di Surabaya). Jurnal Ilmu Manajemen Vol. 7 No. 1 Universitas Negeri Surabaya.

13. Hartanto J (2017). Pengaruh Pemulihan Layanan Terhadap Loyalitas Pelanggan Pada Belanja Online. Jurnal Manajemen Pemasaran Petra.

14. Henry Jones (2015). Putting it Right: Service Failure and Customer Loyalty in UK Banks. International Journal of Bank Marketing.

15. Hoffman \& Batteson (2016), "Persepsi kebutuhan keadilan dan evaluasi pemulihan: kontingensipendekatan ", European Journal of Marketing, Vol. 34 No. 3/4, hlm.418-433

16. Hurriyati, Ratih, Manajemen Pemasaran Jasa dan Bauran Pemasaran, Jakarta: Alfabeta, 2010.

17. Keller, Kevin Lane and Kotler, Philip.2016. Marketing Management. Edition 15.England: Pearson Educational Limited.

18. Kotler, Philip and Gary Amstrong. 2016. Prinsip-prinsip Pemasaran. Edii13. Jilid 1. Jakarta:Erlangga.

19. Kuncoro, Mudrajad. 2019. Metode Riset untuk Bisnis dan Ekonomi. Edisi 3. Penerbit Erlangga.

20. Lovelock, Christopher, Jochen Wirtz, \& Jacky Mussry. 2011. Pemasaran Jasa. edisi 7. Jakarta: Erlangga.

21. Manap A. 2016. Revolusi Manajemen Pemasaran. Edisi Pertama, Mitra. Wacana Media, Jakarta.

22. Mayer, K.et al. (2015), "Hubungan antara perilaku mengeluh konsumen dan pemulihan layanan: sebuah integrative review", Jurnal Internasional Manajemen Perhotelan Kontemporer, Vol. 22 No.7, hlm.975-991.

23. McColl-Kennedy, JR dan Sparks, BA (2013), "Penerapan teori keadilan untuk kegagalan layanan danpemulihan layanan", Jurnal Penelitian Layanan, Vol. 5 No. 3, hlm.251-266.

24. Melisa dan Asnawati (2017). Pengaruh Service Recovery terhadap Loyalitas yang di Mediasi Kepuasan Konsumen pada Jasa 
Syifa Sakinah et.al. The role of the program of development of Corporate Culture in moderating the values of the company against the employee engagement in PT PLN (Persero) Parent Unit is the Region of North Sumatra

Bengkel Sipatuo Motor. Prosiding Seminar Nasional Manajemen dan Ekonomi Bisnis Vol. 1. Universitas Mulawarman.

25. Morgan, et al. (2019), "Teori komitmenkepercayaan pemasaran hubungan", TheJurnal Pemasaran, Vol. 58 No. 3, hlm. 20-38.

26. Parasuraman, A. (2011), "Sebuah model matematis dari kegagalan layanan danstrategi pemulihan", Ilmu Keputusan, Vol. 35, No. 3, hlm.493-525.

27. Priyanko Guchait et al (2018). Examining Stealing Thunder as a New Service Recovery Strategy: Impact on Customer Loyalty. International Journal of Contemporary Hospitality Management. https://doi.org/10.1108/IJCHM-02-20180127.

28. Raquel Tabita, dkk (2017). Analisa Pengaruh Service Recovery Terhadap Loyalitas Konsumen. Jurnal Hospitality dan Manajemen Jasa Vol. 5 No.2.

29. Reichheld, FF, Markey, RG, Jr. dan Hopton, C. (2016), "Efek loyalitas-hubungan antaraloyalitas dan keuntungan", European Business Journal, Vol. 12 No. 3, hlm.134.

30. Rohmat Khoiri (2017). Pengaruh Service Recovery terhadap Loyalitas Pelanggan. Jurnal Manajemen Universitas Muhammadiyah Purworejo.

31. Roshana Gul (2014). The Relationship between Reputation, Customer Satisfaction, Trust, and Loyalty. Journal of Public Administration and Governance Vol. 4 No. 3. ISSN 2161-7104.

32. Schiffman, L.G., Hansen, H. and Kanuk, L. (2011) Consumer Behavior: A European Outlook. Financial Times Prentice Hall, New York.

33. Situmorang, Syafrizal Helmi dan Muslich Lufti. 2012. Analisis Data untuk Riset. Manajemen dan Bisnis. Edisi 2. Medan: USU Press

34. Soussa, R. Voss C. (2019). The Effects of Service Failures and Recovery on Customer Loyalty in E-Service An Empirical. International Journal of Operations and
Production Management Vol. 29 No. 8. ISSN: 0144-3577.

35. Sugiyono. 2011. Metode Penelitian Kuantitatif, Kualitatif, dan $R \& D$. Cetakan 14. Bandung: Alfabeta.

36. Suna La and Beomjoon Choi (2012). The Role Of Customer Affection And Trust In Loyalty Rebuilding After Service Failure And Recovery. The Services Industries Journal Vol. 32 No. 1.

37. Susanto. 2014. Value Marketing. Paradigm Baru Pemasaran. Quantum Bisnis dan Manajemen, Jakarta.

38. Tjiptono, Fandi. 2015. Pemasaran Jasa. Edisi 4. Yogyakart: Andi Offset. 4.

39. Top Brand Award. (2020). Top Brand Index. Diakses 10 Juli 2020. www.topbrandindex.com.2019.

40. Vania Valencia Liwijaya (2017). Pengaruh Service Recovery Terhadap Customer Loyalty dengan Customer Satisfaction Sebagai Variabel Perantara Pada Restoran Di Surabaya. Jurnal Manajemen Pemasaran Petra.

41. Xuhui Wang and Qilin Zhang (2018). Does Online Service Failure Matter to Offline Customer Loyalty in the Integrated MultiChannel Context? The Moderating Effect of Brand Strength. International Journal of Service Theory and Practice. https://doi.org/10.1108/JSTP-01-2018-0013.

42. Wingsati Wahyu Eka dan Dorojatun Prihandono (2017). Pengaruh Penanganan Kegagalan Layanan, Kepercayaan, dan Gaya Hidup Terhadap Loyalitas Pelanggan Melalui Kepuasan. Management Analysis Journal.

43. Zemke, R., Connellan, T. (2010), Layanan Elektronik, AMACOM, New York, NY.

How to cite this article: Sakinah S, Nazarudin, Sadalia I. The role of the program of development of Corporate Culture in moderating the values of the company against the employee engagement in PT PLN (Persero) Parent Unit is the Region of North Sumatra. International Journal of Research and Review. 2021; 8(2): 74-82. 